\title{
Use of water treatment sludge in Self-Compacting Mortar (SCM)
}

\author{
Uso do lodo de tratamento de Água em Argamassa Autoadensável (AAA) \\ Utilización de lodos de tratamiento de aguas en Morteros Autocompactantes (MCA)
}

Received: 12/23/2021 | Reviewed: 12/30/2021 | Accept: 01/06/2022 | Published: 01/17/2022

\author{
Ana Paula Teixeira da Silva \\ ORCID: https://orcid.org/0000-0001-7084-1305 \\ Universidade Federal de Itajubá, Brazil \\ E-mail: anapts@unifei.edu.br \\ Lucas Ramon Roque da Silva \\ ORCID: https://orcid.org/ 0000-0003-0387-622X \\ Universidade Federal de Itajubá, Brazil \\ E-mail: lucasramonroque@gmail.com \\ Vander Alkmin dos Santos Ribeiro \\ ORCID: https://orcid.org/ 0000-0003-0260-2454 \\ Universidade Federal de Itajubá, Brazil \\ E-mail: vanderalkmin@gmail.com \\ Mírian de Lourdes Noronha Motta Melo \\ ORCID: https://orcid.org/0000-0001-9668-7799 \\ Universidade Federal de Itajubá, Brazil \\ e-mail:mirianmottamelo@unifei.edu.br \\ Paulo Cesar Gonçalves \\ ORCID: https://orcid.org/0000-0001-7391-9972 \\ Universidade Federal de Itajubá, Brazil \\ E-mail: pauloxg9@unifei.edu.br \\ Marcia Viana Lisboa Martins \\ ORCID: https://orcid.org/ 0000-0002-6900-6350 \\ Universidade Federal de Itajubá, Brazil \\ E-mail: marciaviana@unifei.edu.br \\ Valquíria Claret dos Santos \\ ORCID: https://orcid.org/0000-0001-7744-3262 \\ Universidade Federal de Itajubá, Brazil \\ E-mail: valquiria@unifei.edu.br \\ Michel Henry Bacelar de Souza \\ ORCID: https://orcid.org/0000-0001-8327-6181 \\ Universidade Federal de Itajubá, Brazi \\ E-mail: michelhenry@unifei.edu.br
}

\begin{abstract}
This paper aims to analyze the characteristics of self-compacting mortar (SCM) with the partial replacement of cement by water treatment sludge (WTS). This replacement aims to contribute to minimize environmental degradation arising from the production of materials used in construction and to give a sustainable destination to the sludge generated in water treatment plants. In this study, the substitution of cement in 10 and 20\% for the WTS from the Itajubá Water Treatment Plant in Minas Gerais was analyzed. The residue was collected, filtered, dried and ground, so that the granulometric analyses could be performed and the data inserted in the EMMA particle packing software. Regarding the mortar, the properties in the fresh state were verified through the spreading and flow tests, in which all mixtures could be defined as self-compacting. Regarding the mechanical properties, compression, flexural tensile and modulus of elasticity tests were performed after 28 days of curing. In the mixtures containing WTS, the mechanical strengths and modulus of elasticity decreased. Furthermore, in the hardened state, a reduction in specific mass and an increase in the voids index and absorption was observed in the traces containing WTS. The results indicate that WTS could be used only for non-structural function. However, the results obtained reinforce the need for further studies on the subject, maintaining the possibility of using the WTS in civil construction.
\end{abstract}

Keywords: Self-Compacting Mortar (SCM); Water Treatment Sludge (WTS); Building construction.

\section{Resumo}

Este artigo visa analisar as características da argamassa auto-compactante (SCM) com a substituição parcial do cimento por lamas de tratamento de água (WTS). Esta substituição visa contribuir para minimizar a degradação ambiental resultante da produção de materiais utilizados na construção e dar um destino sustentável às lamas geradas nas estações de tratamento de água. Neste estudo, foi analisada a substituição de cimento em 10 e $20 \%$ para a ETAR da Estação de Tratamento de Água de Itajubá, em Minas Gerais. O resíduo foi recolhido, filtrado, seco e moído, para que as análises 
granulométricas pudessem ser realizadas e os dados inseridos no software de embalagem de partículas EMMA. Relativamente à argamassa, as propriedades no estado fresco foram verificadas através dos testes de espalhamento e fluxo, em que todas as misturas puderam ser definidas como auto-compactantes. Em relação às propriedades mecânicas, foram realizados ensaios de compressão, tração flexural e módulo de elasticidade após 28 dias de cura. Nas misturas contendo WTS, as resistências mecânicas e o módulo de elasticidade diminuíram. Além disso, no estado endurecido, foi observada uma redução da massa específica e um aumento do índice de vazios e absorção nos traços contendo WTS. Os resultados indicam que o WTS só poderia ser utilizado para funções não estruturais. No entanto, os resultados obtidos reforçam a necessidade de mais estudos sobre o assunto, mantendo a possibilidade de utilização do WTS na construção civil.

Palavras-chave: Argamassa Auto-Compactante (SCM); Lamas de Tratamento de Água (WTS); Construção de edifícios.

\begin{abstract}
Resumen
Este trabajo tiene como objetivo analizar las características del mortero autocompactante (MCA) con la sustitución parcial del cemento por lodos de depuradora (LDA). Esta sustitución pretende contribuir a minimizar la degradación ambiental derivada de la producción de los materiales utilizados en la construcción y dar un destino sostenible a los lodos generados en las plantas de tratamiento de aguas. En este estudio, se analizó la sustitución del cemento en un 10 y un 20\% para los LODs de la Estación de Tratamiento de Agua de Itajubá, en Minas Gerais. El residuo se recogió, se filtró, se secó y se molió, para poder realizar los análisis granulométricos e introducir los datos en el software de empaquetamiento de partículas EMMA. En cuanto al mortero, las propiedades en estado fresco se verificaron mediante los ensayos de extensión y flujo, en los que todas las mezclas pudieron definirse como autocompactantes. En cuanto a las propiedades mecánicas, se realizaron ensayos de compresión, tracción a flexión y módulo de elasticidad tras 28 días de curado. En las mezclas que contenían WTS, las resistencias mecánicas y el módulo de elasticidad disminuyeron. Además, en el estado endurecido, se observó una reducción de la masa específica y un aumento del índice de huecos y de la absorción en las trazas que contenían WTS. Los resultados indican que el WTS podría utilizarse únicamente para una función no estructural. Sin embargo, los resultados obtenidos refuerzan la necesidad de realizar más estudios sobre el tema, manteniendo la posibilidad de utilizar el WTS en la construcción civil.
\end{abstract}

Palabras clave: Mortero Autocompactante (MCA); Lodos de Tratamiento de Aguas (WTS); Construcción de edificios.

\title{
1. Introduction
}

Idealized as the revolutionary advance of conventional concrete, whose particular characteristic is self-compaction in the molds without the need for mechanical vibration, self-compacting concrete (SCC) was originally developed to compensate for a growing shortage of skilled labor (Okamura \& Ouchi, 2003). The possibility of faster concrete construction coupled with increased durability, increased productivity, better surface finish of concrete elements, reduced local labor and reduced noise level motivated the continued use accompanied by several physical and mechanical research of SCC. The main property that differs SCC from conventional concrete is its full compaction capacity even in structures with high reinforcement density or narrow sections and this property is governed by the high fluidity and cohesion mechanisms of the mixture (Dinakar, 2012). Another important property of SCC is the stability and resistance to segregation ensuring the viscosity of the paste and mortar, components of SCC. To ensure these SCC properties, it is essential the composition of raw materials, the incorporation of chemical and mineral additives, a greater incorporation of fine materials, an adequate packing of aggregates and the watercement ratio, as well as superplasticizer additives (SP) and sometimes viscosity modifying agents (VMA). An alternative to the high consumption of cement as a fine material in the production of SCC is the addition of minerals that contribute to selfcompacting, resistance to segregation, viscosity and improves workability in the fresh state.

The use of industrial waste in SCC, besides collaborating with the rheological properties of the fresh state and the mechanical properties in the hardened state, provides cost reduction and environmental impact, since they are commonly discarded in nature (Mehta \& Monteiro, 2008).

One of the challenges of civil construction is the reduction of material and energy consumption, since the cement industry alone is responsible for 5 to $8 \%$ of the world's carbon dioxide $\left(\mathrm{CO}_{2}\right)$ emissions (Buselatto et al., 2019).

On the other hand, water treatment plants, during the physical-chemical process of treating raw water into drinking water, generate a large amount of waste, composed mainly of sand and silt, which can be used to make concrete. It is estimated 
that the daily production of sludge in the world is greater than 10,000 tons and that a typical water treatment plant produces about 100,000 tons per year (Ahmad et al., 2016).

WTS is classified as solid waste, standard 10.004 (ABNT, 2004), and as such should be treated and disposed of in an environmentally appropriate manner, prioritizing the reduction, reuse and recycling, as provided in the National Solid Waste Policy, Federal Law 12.305 (Câmara dos Deputados, 2017). However, it is common the release of WTS into bodies of water without prior treatment (Katayama et al., 2015) and without the granting of effluent dilution, constituting a serious liability generated by sanitation companies (Gessica Zila Batista dos Santos et al., 2018). As a consequence, there is siltation and contamination of waterways due to its composition of organic matter and solids and the presence of chemical substances added during the treatment processes. At other times, after dehydration, WLT is applied to landfills and soil. However, the difficulty in finding available areas and the costs related to landfill operation and maintenance, in addition to the risks of soil contamination, make this alternative unviable in many locations (Ahmad et al., 2016).

In general, the characteristics of WTS are considered suitable for its potential use as a building material, consisting of a safe alternative for sludge disposal (Ahmad et al., 2016). WTS has varying concentrations of organic and suspended matter, coagulants, chemical elements, and microorganisms (Babatunde \& Zhao, 2007). In general, WTS is composed of oxides of silicon ( $\mathrm{Si}$ ), aluminum ( $\mathrm{Al}$ ) and iron (Fe), and the minerals kaolinite, illite, hematite and quartz (Gessica Zila Batista dos Santos et al., 2018). The quantity and quality of WTS generated in water treatment plants depends on the quality of the raw water, the treatment method applied and the final quality required (Ahmad et al., 2016). The impurities present in raw water such as sand, silt, clay, humic particles, and other contaminants come from surface runoff and the discharge of urban and industrial effluent discharged into waterways.

The composition of these vary depending on the characteristics of land use and occupation in the catchment, the characteristics of the discharges and the weather (Araújo et al., 2015). Chemical substances such as aluminum salts (e.g., $\mathrm{Al}_{2}$ $\left(\mathrm{SO}_{4}\right) 3.18 \mathrm{H}_{2} \mathrm{O}$, poly aluminum chloride) or iron salts (e.g., $\mathrm{FeCl}_{3} .6 \mathrm{H}_{2} \mathrm{O}, \mathrm{FeCl}_{2}, \mathrm{FeSO}_{4} .7 \mathrm{H}_{2} \mathrm{O}$ ), on the other hand, result from the addition of coagulant reagents added during the treatment process to remove colloidal and suspended impurities (Ahmad et al., 2016). Therefore, the dosage of coagulants used in treatment processes, results in changes in the quantity and quality of sludge production (Ahmad et al., 2016).

The use of WTS in the production of SCC presents itself as a sustainable alternative that seeks to reduce consumption and minimize the environmental impacts resulting from the high extraction of natural resources and energy in civil construction and also provide appropriate solutions to the disposal of waste from water treatment plants (Gessica Zila Batista dos Santos et al., 2018). Studies have been developed with the addition of up to $10 \%$ of WTS sludge in mortars and products with non-structural purposes as a replacement for sand. In this context, proposed in their paper durability tests of concretes with addition of dried sludge from water treatment plant Yagüe et al. (2005). The specimens were submitted to different combined types of attacks, such as cycles in fresh water, sea water and sulfate solution and accelerated carbonation.

The results of the tests showed that the concrete with added sludge, submitted to sulfate solution, suffered variations in properties, leaching of hydrated cement components and changes in the organic matter present in the sludge caused by the basic medium played an important role, leading to increased porosity. The accelerated carbonation test showed that the porosity of the concrete increases with the higher concentration of sludge (Ribeiro et al., 2021).

On the other hand, specimens with added sludge submitted to freshwater and seawater did not produce significant changes compared to the base concrete. Sales e Souza, (2005) evaluated in their study the possibility of recycling water treatment sludge in construction and demolition waste recycling plants in the production of mortars and concretes from the replacement of fine aggregates by dry sludge in proportions of $1 \%$ to $5 \%$, with a base specimen with $0 \%$ replacement. The authors also used recycled construction debris as a replacement for coarse aggregates. The results of the specimens with replacement of fine 
aggregates by sludge showed an increase in compressive strength compared to control concrete, and the best result was obtained with a mix with replacement of sand by $2 \%$ of sludge, showing an increase of about $27 \%$ compared to control concrete and a reduction in water absorption. The use of the dry sludge powder residue, the result of coagulation/flocculation treatment of wastewater from the processing of Andesite, a type of marble rock of volcanic origin, commonly used in architecture, construction, and art since ancient times, used as an additive to concrete was studied by Sogancioglu et al. (2013).

Tests of reference concrete and concrete with addition of dried sludge in the fresh state and in the hardened state were performed and the results showed that the slump values, in general, were higher than those obtained in the reference concrete and the compressive strength tests, all specimens with addition of dried sludge from Andesita showed a reduction of values when compared to the reference concrete.

Liu et al. (2020) studied the partial replacement of sand by oven-dried drinking water treatment sludge in the production of concrete blocks. The concrete blocks produced with sludge contents varying in proportions from $0 \%$ to $30 \%$, treated by early carbonation curing, showed an increase in compressive strength and microstructural tests the formation of ettringites, resulting from the presence of alum and gypsum in the sludge residue and the early carbonation curing process decomposed these ettringites into calcium carbonates, causing a refining effect of the pores of the specimens.

Buselatto et al. (2019) evaluated the effects of sand replacement contents by WTS $(2.5 \%, 5 \%, 7.5 \%$ and $10 \%$ by mass) and w/c ratio $(0.4,0.5$ and 0.6$)$ on physical (specific mass, porosity and water absorption by immersion) and mechanical properties (axial compressive strength and tensile strength by diametral compression) at different ages (7, 28 and 91 days).

The results showed that there was a reduction of properties compared to the reference concrete, but considering the highest w/c ratio (0.60), all concretes presented values higher than $25 \mathrm{MPa}$ of compressive strength. The Figure 1 shows the research field related to the theme sludge, water treatment plant, concrete and mortar, trend of the research field, theme sludge with cementitious composites. This search was conducted in the Scopus database and reveals the small number of studies on the subject, despite an increase in the last decade, with the year 2020 being the one with the highest number of publications (Souza et al., 2021). 
Figure 1: Trend of the research field, theme sludge with cementitious composites.

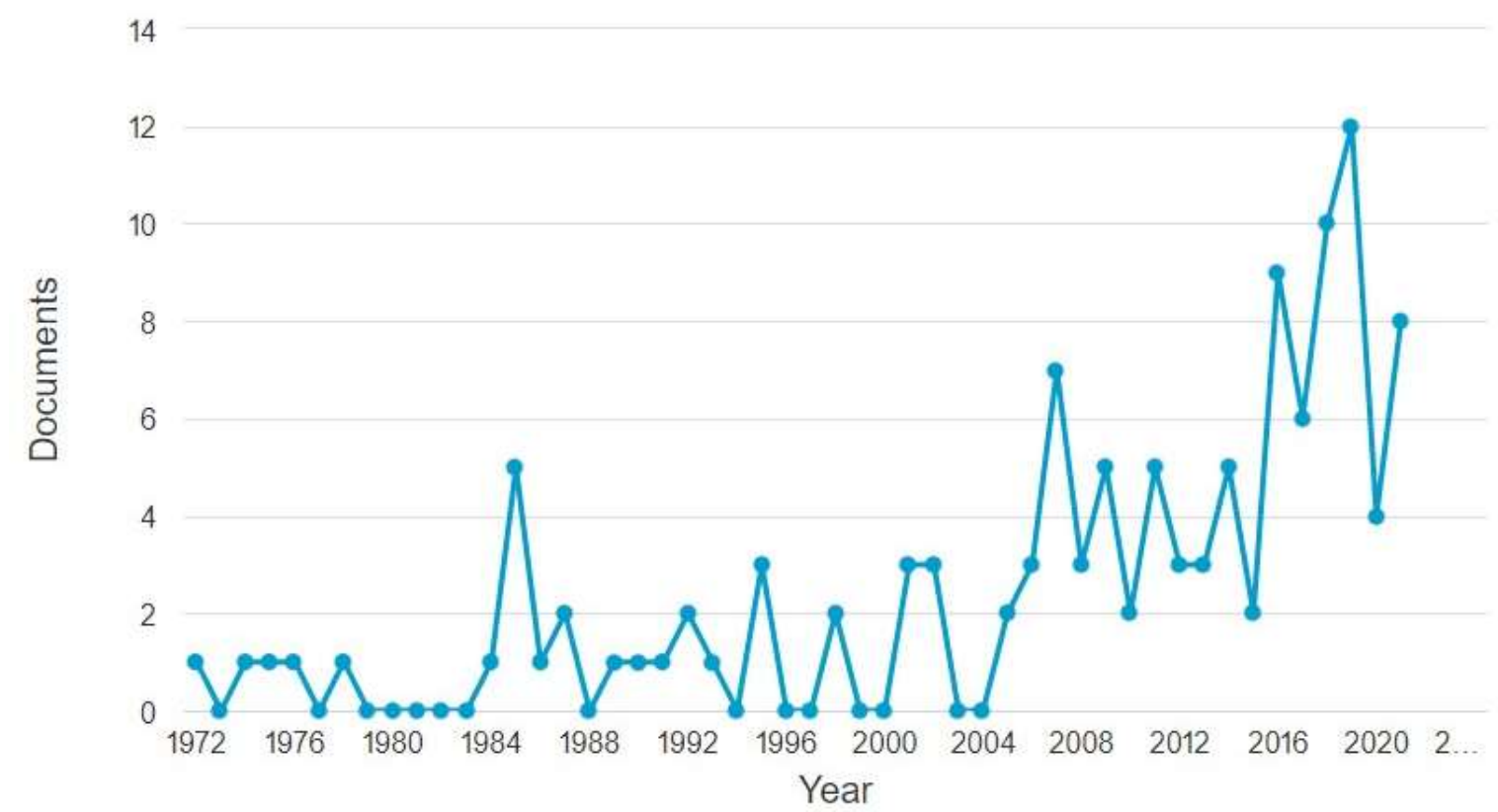

Source: Souza et al. (2021).

In light of the above, this study aims to analyze the replacement of cement in 10 and $20 \%$ by WTS in the production of mortar, in order to reduce the impact of the extraction of materials for construction and give an appropriate destination for the sludge generated in the water treatment plant of Itajubá Minas Gerais.

\section{Materials and Methods}

\subsection{Materials}

CP V-ARI cement, used in this experiment, has a finer grinding of Portland clinker, thus adding a material with a favorable granulometry to obtain SCM. In this case, the specific gravity, specific surface, and laser granulometry (performed with the Mastersizer equipment from Malvern Instruments) of the cement were evaluated according to current regulations. Granulometry, specific gravity, unit mass, and water absorption tests were also carried out for the sand, according to current regulations.

The sludge was collected from the decanters of the Water Treatment Plant (WTP) of Itajubá, Minas Gerais. The Itajubá WTP is of the convencional type and with treatment capacity of $0,450 \mathrm{~m} 3 / \mathrm{s}$.

The water is from two water springs, Toledos Stream $\left(0,07 \mathrm{~m}^{3} / \mathrm{s}\right)$ and Sapucaí River $\left(0,27 \mathrm{~m}^{3} / \mathrm{s}\right)$, with distinct characteristics. The Stream Toledos is a protected source of water, while the Sapucaí river catchment is located upstream of Itajubá and receives the effluent from 3 municipalities.

The WTP treats an average daily volume of $16,989.6 \mathrm{~m}^{3}$. The chemical substances used in the water treatment are hydrated lime $\left(\mathrm{Ca}(\mathrm{OH})_{2}\right)$, cationic polymer, polyaluminium chloride $(\mathrm{PAC})$, chlorine gas $\left(\mathrm{Cl}_{2}\right)$ and fluosilicic acid $\left(\mathrm{H}_{2} \mathrm{SiF}_{6}\right)$.

The treatment units are composed of 1 Parshall flume, 14 mechanized flocculators, 4 decanters with lamellar plates, and 6 descending filters. The decanters are cleaned every 15 days, 2 units are washed each time, the washing duration is 45 minutes and the water volume used in each wash is $470 \mathrm{~m}^{3}$ (Ministério do Desenvolvimento Regional, 2020). The filters are washed in counter-current (ascending direction), 1 filter is washed every 70 hours, the duration of washing is 12 minutes and the volume of water spent is $180 \mathrm{~m}^{3}$. The daily volume of water spent cleaning the decanters and filters is $125.3 \mathrm{~m}^{3}$. The average daily sludge 
production is $2 \mathrm{~m}^{3}$ (dry or wet basis), with a solids content of $2 \%$. The waste is discharged without prior treatment into the municipal drainage network and conducted back to the Sapucaí river.

The residue (a little over $2 \mathrm{~kg}$ ) was collected between the end of February and beginning of March 2020. After collection, the initial drying process was based on the method applied by Ribeiro (2012) in which WTP is placed in a structure containing a geotextile blanket attached to a cylindrical gallon, in order for the WTP to be retained in the blanket, while the gallon stores the passing water.

According to Santos (2016), generally, the drying of the sludge occurs at temperatures between 100 and $110^{\circ} \mathrm{C}$ for 24 to 48 hours. Thus, after retaining the WTS in the blanket, it was placed in porcelain containers and taken to the oven at a temperature of $100^{\circ} \mathrm{C}$, first, for 24 hours. After 24 hours, it was observed that the WTP was still too wet. Thus, it was decided to leave the WTS in the oven for another 24 hours, with total water evaporation occurring during the 48 hours.

After the collection and drying processes, there is the WTS milling stage. Initially, the WTS was manually ground in a pestle, in order to reduce the size of its particles to facilitate mechanical grinding. Next, the WTS was taken to the rotary steel ball mill and, after initial tests, a ball/sludge ratio of approximately 1/0.1 was chosen, i.e., 1 kilogram of balls to 0.1 kilogram of sludge, for a period of 3 hours. After this process, the WTS acquired a powder appearance.

After the collection, drying and grinding processes of the WTS, it was submitted to laser diffraction granulometry (performed with the Mastersizer equipment from Malvern Instruments) and, considering that the sludge would replace part of the cement, the test was performed to obtain the specific mass, using the standard proposed for the specific mass of cement. In ad Edition, the pH and electrical conductivity of the WTS were obtained using the methodology presented by Eaton et al. (2007).

The additive used in the SCM is superplasticizer additives. It was decided to add metakaolin to increase the percentage of fines, improving the mixture cohesion. The tests performed were specific gravity and laser granulometry. The high specific surface area improves rheological aspects by optimizing the granulometric distribution of the paste, contributing to water retention, increased cohesion, reduced exudation, and segregation (Medina, 2011).

In order to analyze the preparation of the SCM, the Elkem Materials Mixture Analyzer (EMMA) software was used. To perform the procedure, the corresponding characteristics of the cement, metakaolin, fine aggregate, and WTS were entered, such as the amount of material in each mix, specific mass, and grain size. After placing the data, the software generated a plot and a data table with the distribution of the particles as a function of their diameter. Thus, a comparison was obtained between the mixture used and the optimal mixture provided by the software, which seeks the best particle packing.

\subsection{Dosage Methods}

With the dosing procedure finished, the mixture preparation began Table 1.

Table 1: Process of obtaining SCM mixtures.

\begin{tabular}{cc}
\hline Time & Blending step \\
\hline 1 minute & Cement, metakaolin, sand, and ground brick (or flooring) \\
1 minute & $80 \%$ of the total volume of water \\
5 minutes & $20 \%$ of the total volume of water + superplasticizer \\
2 minutes & Rest in mortar \\
1 minute & Mix again in the mortar \\
\hline
\end{tabular}

Source: Own Authors (2022). 


\subsection{Characterizations}

Regarding the classification of the self-compacting mortar, it was necessary to analyze its properties in the fresh state by means of the mini slump test, which determines the spreading of the mixture, and the funnel- $\mathrm{V}$ test, which observes the flow of the composition.

The axial compressive strength and flexural tensile strength tests were performed. Three cylindrical specimens (CP) were molded, $50 \mathrm{~mm}$ in diameter, and $100 \mathrm{~mm}$ high for the compressive test, and three prismatic $\mathrm{CP}, 40 \mathrm{~mm}$ wide, $40 \mathrm{~mm}$ high, and $160 \mathrm{~mm}$ long for the flexural.

In addition, the specific mass, void index and absorption, and modulus of elasticity were analyzed. Briefly, the tests and their respective standards are shown in Table 2:

Table 2: Tests performed for mortar with WTS.

\begin{tabular}{|c|c|c|}
\hline Tests & & Normas ABNT/equipamentos \\
\hline Specific Mass & \multirow{2}{*}{ CP V-ARI } & ABNT NBR 16605, 2017 \\
\hline Laser granulometry & & Malvern Instruments Ltda, Mastersizer \\
\hline Granulometry & \multirow{4}{*}{ Sand } & ABNT NBR NM 248, 2003 \\
\hline Specific Mass & & ABNT NBR NM 52, 2009 \\
\hline Unit Mass & & ABNT NBR NM 45, 2006 \\
\hline Water absorption & & ABNT NBR NM 30, 2001 \\
\hline Specific Mass & \multirow{4}{*}{ WTS } & ABNT NBR 16605, 2017 \\
\hline Laser granulometry & & Malvern Instruments Ltda, Mastersizer \\
\hline Hydrogen potential $\mathrm{Ph}$ & & EATON et al., (2005) \\
\hline SEM and EDS & & - \\
\hline Specific Mass & \multirow{2}{*}{ Metakaolin } & ABNT NBR 16605, 2017 \\
\hline Laser granulometry & & Malvern Instruments Ltda, Mastersizer \\
\hline Mini slump & \multirow{2}{*}{ Fresh state } & Gomes e Barros (2009) \\
\hline Funnel-V & & Gomes e Barros (2009) \\
\hline Compressive Strength & \multirow{6}{*}{ Hardened State } & ABNT NBR 5739, 2018 \\
\hline Tensile Strength & & ABNT NBR 7222, 2011 \\
\hline Modulus of Elasticity & & ABNT NBR 8522-1, 2021 \\
\hline Specific Mass & & ABNT NBR 9778, 2005 \\
\hline Void index & & ABNT NBR 9778, 2005 \\
\hline Water absorption & & ABNT NBR 9778, 2005 \\
\hline
\end{tabular}

Source: Ribeiro et al. (2021; Silva et al. (2020). 


\section{Results and Discussion}

The results of the characterization tests for cement, metakaolin, sand and WTS can be seen in Table 3.

Table 3: Essential characterization results of the materials used in this study.

\begin{tabular}{ccccc}
\hline Material & $\begin{array}{c}\text { Specific gravity } \\
(\mathrm{g} / \mathrm{cm} 3)\end{array}$ & $\begin{array}{c}\text { Unit Mass } \\
\left(\mathrm{g} / \mathrm{cm}^{3}\right)\end{array}$ & Absorption (\%) & $\begin{array}{c}\text { Fineness Modulus } \\
(\mathrm{MF})\end{array}$ \\
\hline Cement & 3.04 & - & - & - \\
\hline Metakaolin & 2.56 & - & - & - \\
\hline Sand & 2.58 & 1.45 & 0.37 & - \\
\hline WTS & 2.35 & - & - & -63 \\
\hline
\end{tabular}

Source: Own Authors (2022).

The WTS of this research has a value of 6.95. As a comparison, the standard ABNT NBR 15900, (2009) establishes that concrete mixing water must have a pH between 6 and 7. The specific mass of the WTS is lower than the specific mass of the sand and cement. Comparing with Brachini et al. (2020) it is verified that, even using sludge from the same treatment plant, the specific masses presented different values. This may be related to the procedure applied by Brachini et al. (2020) since the sludge residue was calcined. These changes may also be related to variations in the quality of raw water and chemicals added in water treatment. The particle size distribution of CP V, metakaolin and WTS was done by means of laser granulometry, and the diameters are shown in Table 6.

Table 4: Particle size distribution of fine materials.

\begin{tabular}{cccc}
\hline & CPV $(\mu \mathrm{m})$ & Metakaolin $(\mu \mathrm{m})$ & WTS $(\mu \mathrm{m})$ \\
\hline $\mathrm{d} 10$ & 2.3 & 2.5 & 2.6 \\
\hline $\mathrm{d} 50$ & 12.5 & 12.4 & 11.7 \\
\hline $\mathrm{d} 90$ & 35.2 & 30.6 & 26.5 \\
\hline
\end{tabular}

Source: Own Authors (2022).

Analyzing the data presented, it can be seen that $10 \%$ of the constituent particles of the WTS have a diameter less than $2.55 \mu \mathrm{m}, 50 \%$ of the particles are smaller than $11.69 \mu \mathrm{m}$ and $90 \%$ of the grains are smaller than $26.48 \mu \mathrm{m}$. Moreover, it is observed a d50 considerably close to that of cement, which is extremely relevant, since one material will replace part of the other.

According to Energy Dispersive Spectroscopy (EDS) analysis the composition of the WTS was estimated to be composed predominantly of carbon, oxygen. The presence of aluminum, iron, silica and titanium was also observed.

The presence of aluminum in significant quantities, around $15 \%$ of the sample, is linked to the use of coagulant in the WTP of the City of Itajubá, aluminum polychloride, which is used as a coagulant for water treatment.

Figure 2 shows the scanning electron microscopy analysis with secondary electrons. The scale used was $10 \mu \mathrm{m}$ with magnification of about 2,000 times. It is observed that the morphologies of the particles are irregular with heterogeneous shapes, with a predominance of powdery particles that coat the larger particles. 
Figure 2: WTS grains from the water treatment plant.

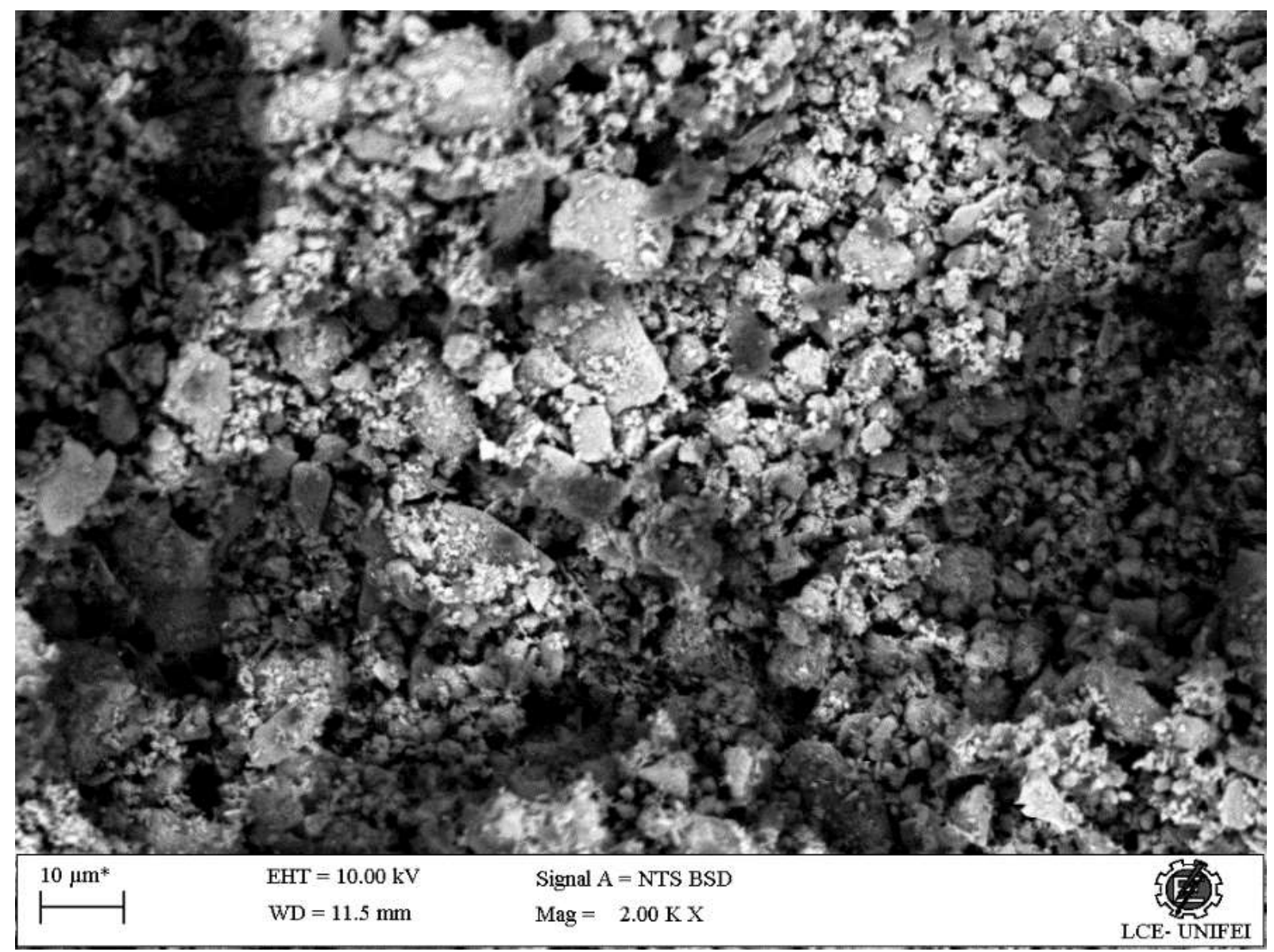

Source: Own Authors (2022).

The curves presented in Figure 3 compare the granulometries of the materials used for the execution of the mortar with sludge. There is a considerable approximation of the granulometry of the sludge with that of the metakaolin and cement. This characteristic is extremely relevant, considering the substitution that was performed in the study. 
Figure 3: Granulometry of the aggregates used in the SCM.

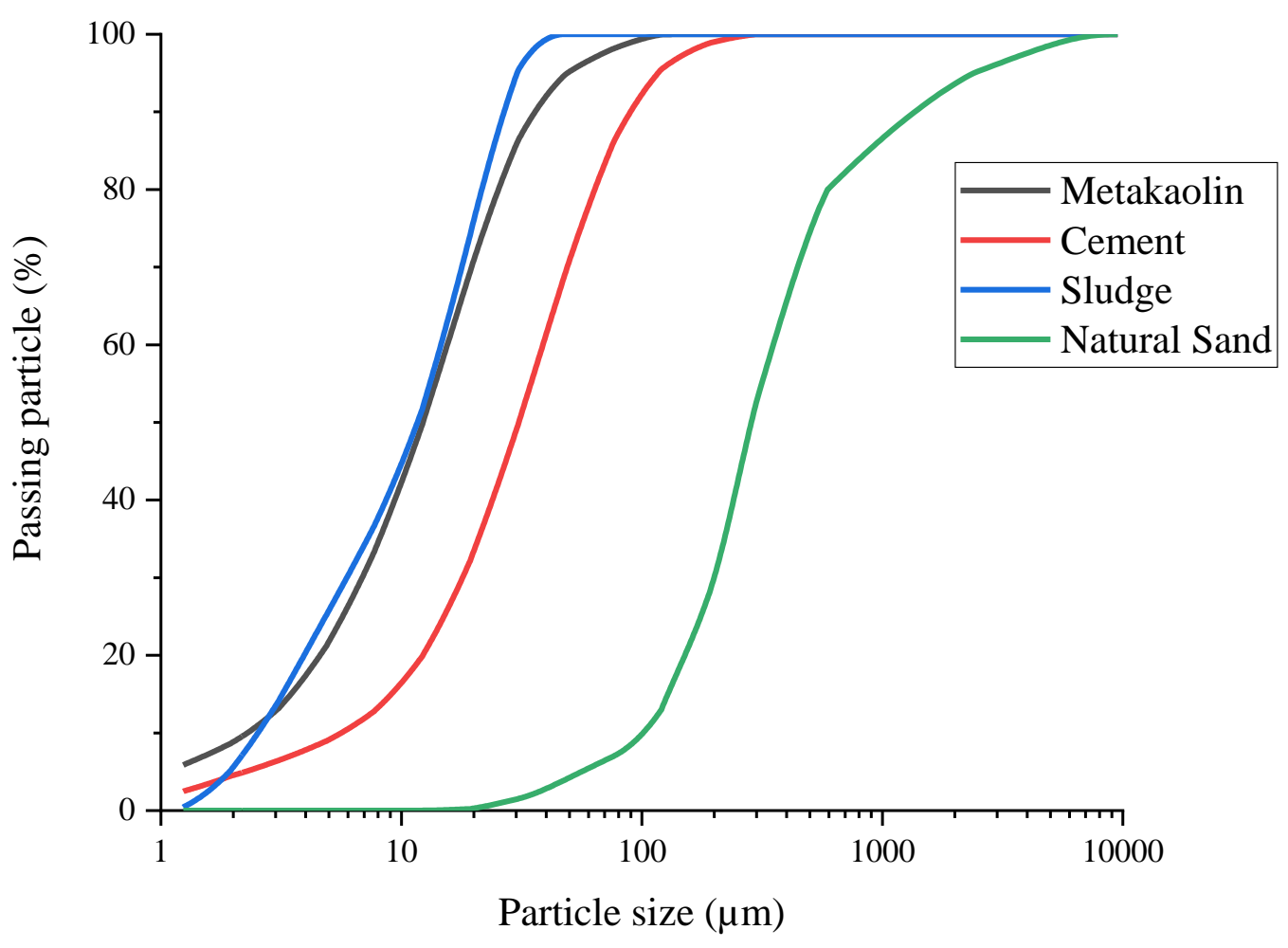

Source: Own Authors (2022).

The curves in Figure 4 and Figure 5 were generated considering the insertion of the specific mass and granulometry of each fine used in the mortar production (cement, metakaolin, residue, and sand), which represent the proximity of the optimal mixture provided by the software and the mixture used.

Figure 4: Curve for the reference mixture.

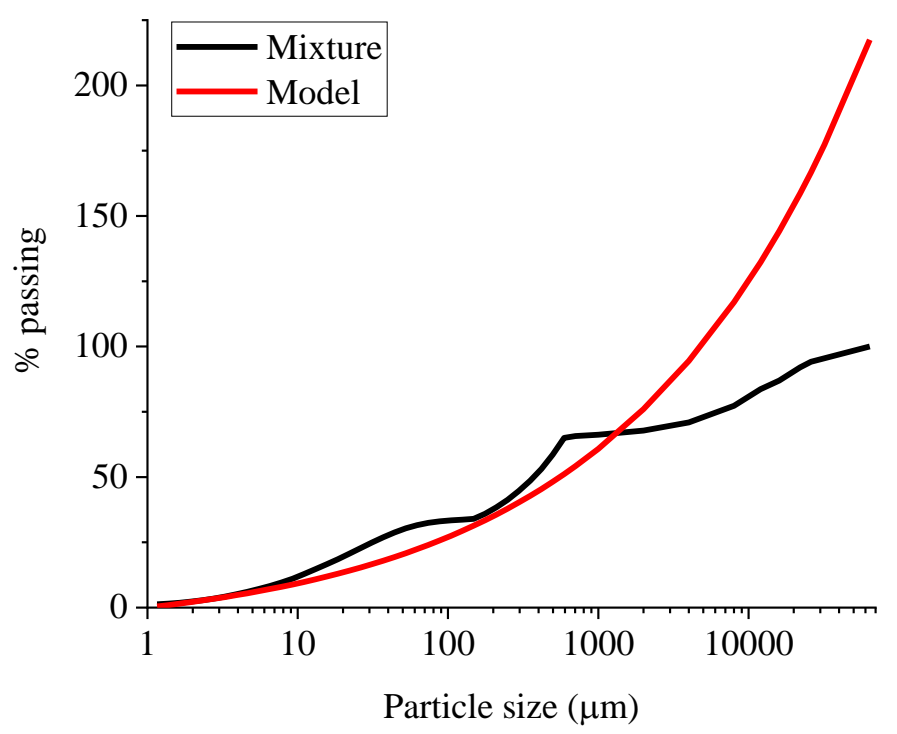

Source: Own Authors (2022). 
Figure 5: Curves for the mixtures with 10\% (left) and 20\% (right) WTP.

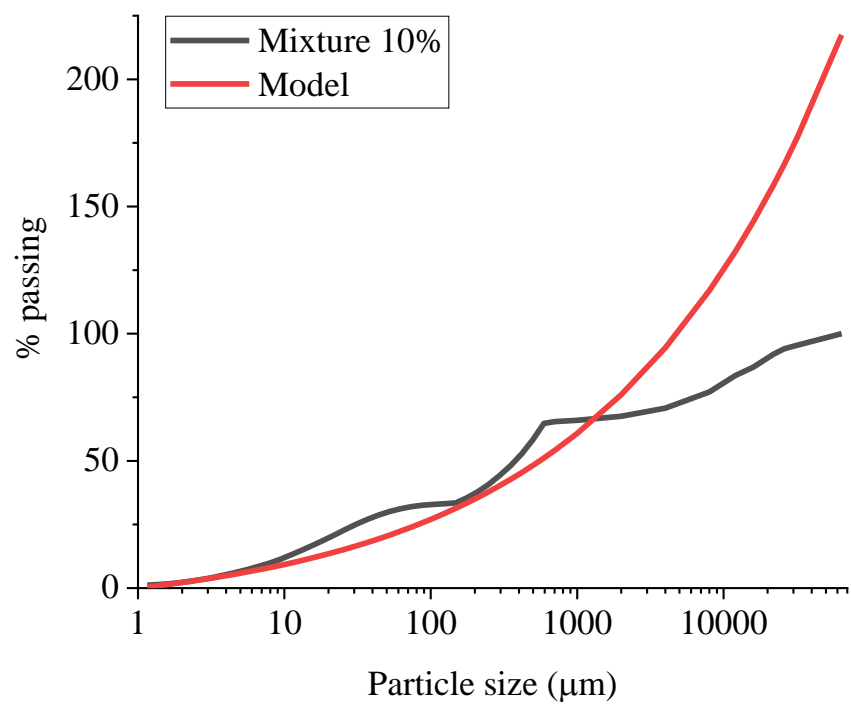

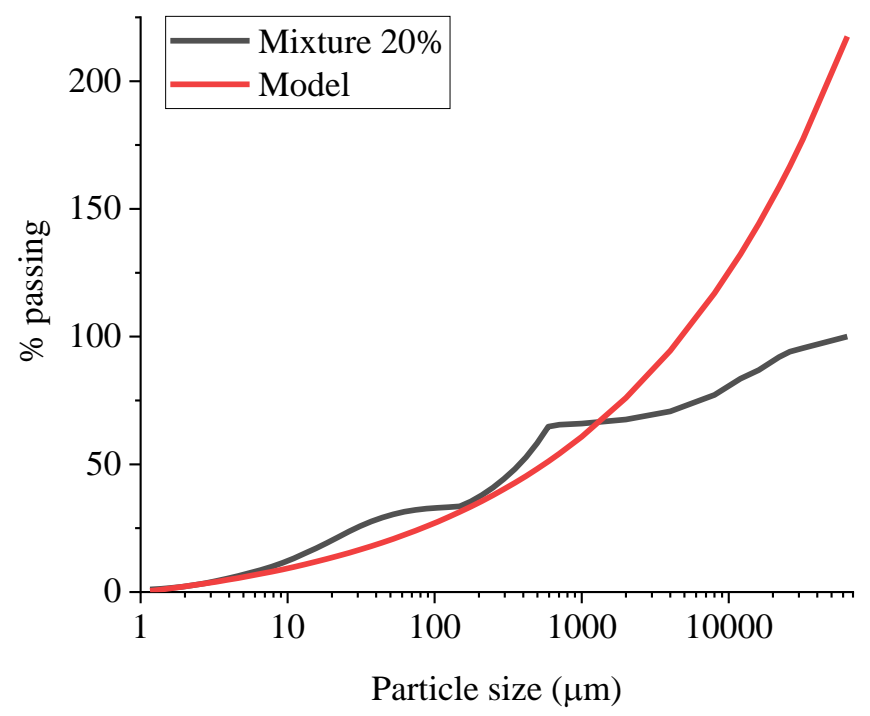

Source: Own Authors (2022).

Analyzing the data obtained by EMMA and the curves in Figure 4 and Figure 5, it can be seen that the insertion of the WTS in the SCM did not significantly modify the proximity of the mixture used and the optimum mixture, considering the reference mixture. Furthermore, by means of the software, the diameter for the smallest and largest particles was determined, equivalent to 1 and $4800 \mu \mathrm{m}$. It was also obtained the value of q, referring to the modulus of the particle packing coefficient, being 0.28 . According to Rodrigues et al. (2022) values less than 0.30 promote good flow capacity.

According to Brachini et al. (2020) small modifications in the proportions of mixtures in mortar with sludge residue may be necessary. These modifications are necessary to achieve the characteristics of self-compacting in the fresh state. This occurs because of the great variety of this raw material, which can have different compositions according to the type of treatment and seasons of the year. In Table 5 is the basic mix and the mixes with 10 and 20\% of WTS replacing the cement.

Table 5: Proportion of the reference, 10 and 20 WTS mixtures.

\begin{tabular}{ccccccc}
\hline Mixtures & Cimente $(\mathrm{g})$ & WTS $(\mathrm{g})$ & Metakaolin $(\mathrm{g})$ & Sand $(\mathrm{g})$ & Water $(\mathrm{g})$ & $\mathrm{Sp} *(\mathrm{~g})$ \\
\hline WTS0 & 1203.00 & 0.00 & 60.07 & 2219.82 & 0.50 & 17.29 \\
WTS10 & 1068.02 & 106.80 & 60.90 & 2285.56 & 0.50 & 21.78 \\
WTS20 & 1050.71 & 210.14 & 52.53 & 2473.81 & 0.50 & 28.92 \\
\hline
\end{tabular}

Sp*: Superplasticizer. Source: Authors.

Thus, it is verified that the proportion of sand in relation to cement in the base mix is a little lower than the other mixes. This situation occurred to correct the exudation present in the mortar mixer, opting for the addition of fines (cement and metakaolin).

Compared to the Brachini et al. (2020) mixture, it can be seen that there was an increase in the w/c ratio, however, this fact caused a considerable reduction in the amount of SP, which was previously thought to make the SCM with WTS more economically feasible. In addition, the increase in the w/c ratio may be linked to the fact that the WTS was not treated, while Brachini et al. (2020) was calcined, reducing the amount of organic matter in the waste. Similarly to what Tafarel et al. (2016) 
describes, that organic matter influences the hydration of cement, causing greater water consumption, it can be observed in Table 9 , a gradual increase in the amount of water, being higher in the replacement of $20 \%$, containing greater amount of WTS and, consequently, higher organic matter content.

Analyzing Figure 7, it can be seen that the mortars showed no exudation or segregation, remaining homogeneous during the fluid state tests. Another visual observation is the fact that the mortar referring to the mixture with 0\% WTS, Figure 7(a), presented a more grayish hue, while the others are close to brown, verifying that the SCM with 20\% sludge, Figure 7(c) is browner, due to a higher amount of waste.

According to Ramirez et al. (2017), the changes in coloration may be linked to the characteristics of the sludge, such as the high content of organic matter, and its chemical composition.

Figure 6 shows the results of the flow and spreading tests (mini slump), so it is possible to analyze the correlation of the flow and spreading properties for all SCM mixtures

Figure 6: Relationship between spreading and flow time of mortar with percentage of replacement of WTS by cement.

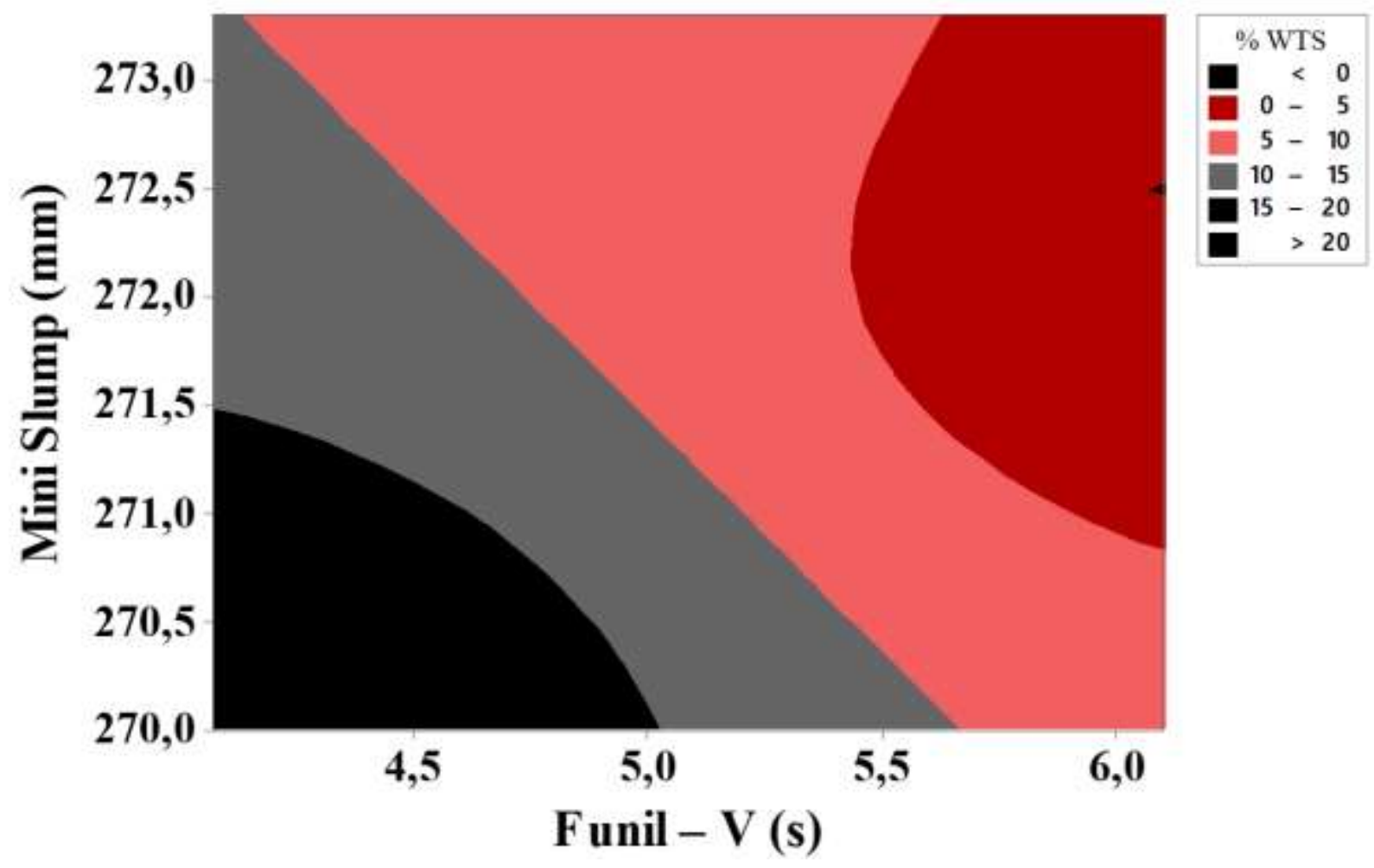

Source: Own Authors (2022). 
Figure 7: Spreading test for mortar with mixture WTS (a) 0\%WTS reference; (b) Mixture 10\%WTS; (c) Mixture 20\%WTS.

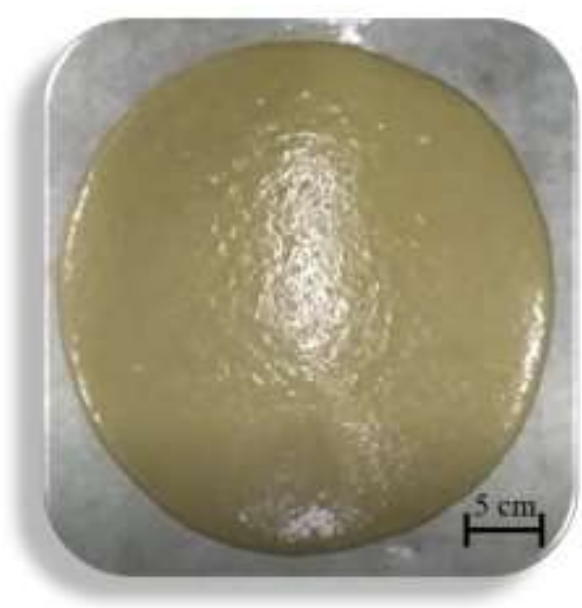

(a)

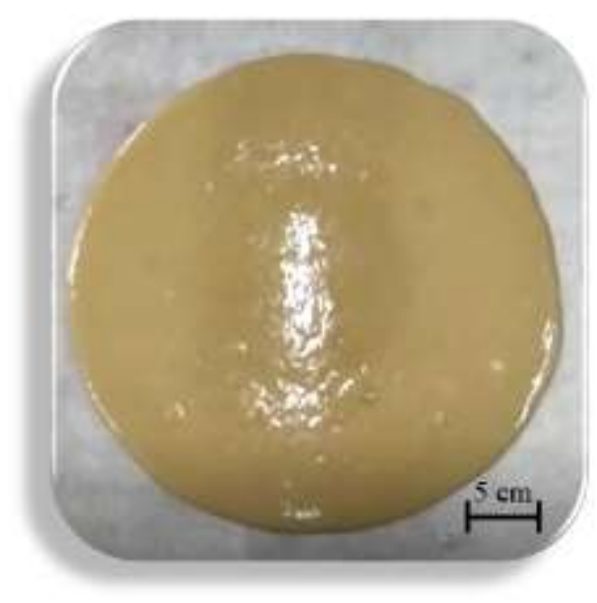

(b)

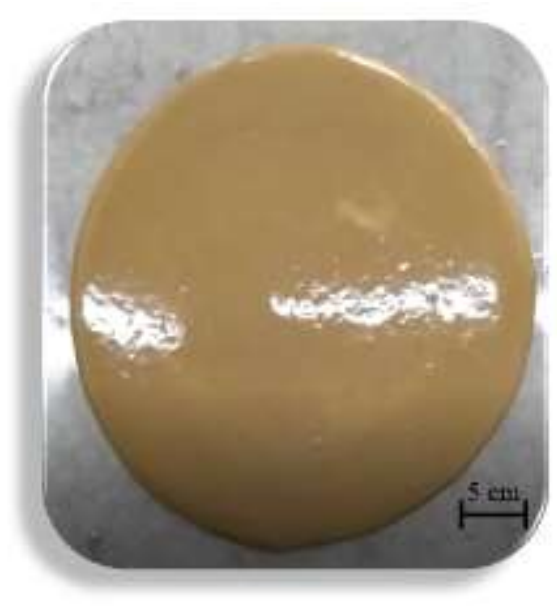

(c)

Source: Own Authors (2022).

The slump flow of the mortars with WTS were within the recommended reference range of 200 to $280 \mathrm{~mm}$ (Gomes \& Barros, 2009). The changes caused by the incorporation of WTS were small, being that for $10 \%$ of WTS there was an increase of $0.30 \%$, and $20 \%$ of WTS there was a decrease of $1.0 \%$ in the slump.

The V funnel test of the WTS mortars were within the recommended reference range of 3.5 to $10.0 \mathrm{~s}$ (Gomes \& Barros, 2009). The results show that there is little change in the viscosity of the mortar. For the substitutions of $10 \%$ and $20 \%$ of WTS, respectively, there is a $0.2 \%$ and $0.3 \%$ decrease in WTS. From Figure X it can be seen that the spreading and flow through the $\mathrm{V}$ funnel are inversely proportional. This is expected for fluids of the nature of cementitious materials that can be classified as Newtonian fluids (Comminal et al., 2020). After performing the tests in the fresh state, three cylindrical and three prismatic specimens were molded in order to analyze the respective mechanical characteristics of the mortar. A cure time of 28 days was considered, as shown in Figure 8. 
Figure 8: Properties in hardened state as a function of cement replacement by $0 \%, 10 \%$ and $20 \%$.

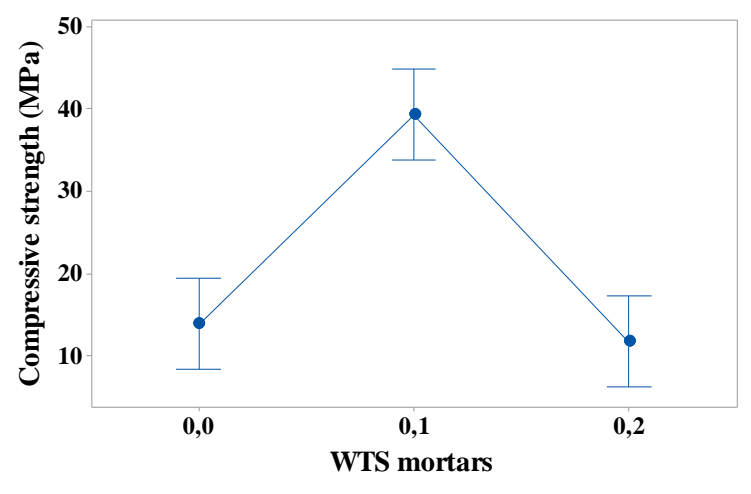

(a)

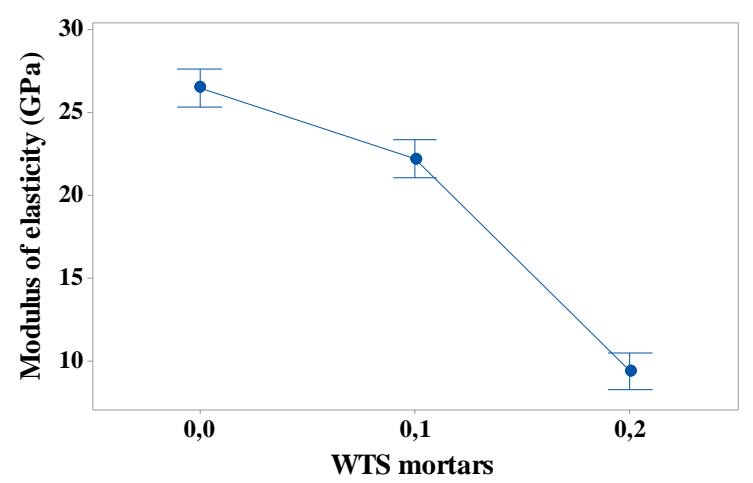

(c)

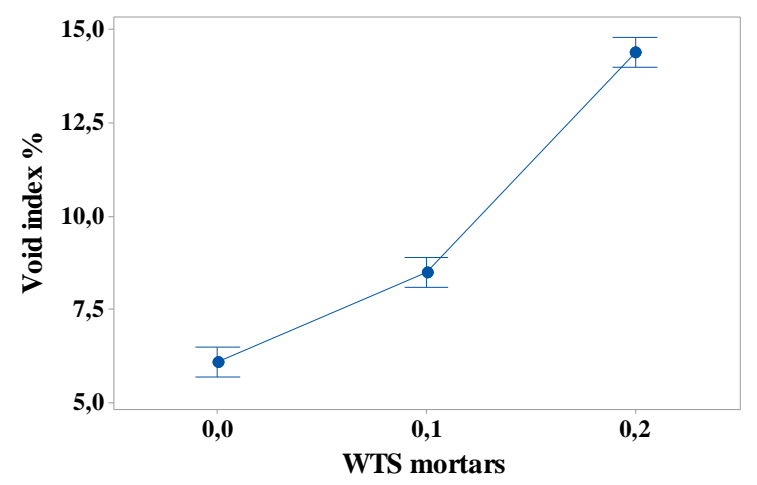

(e)

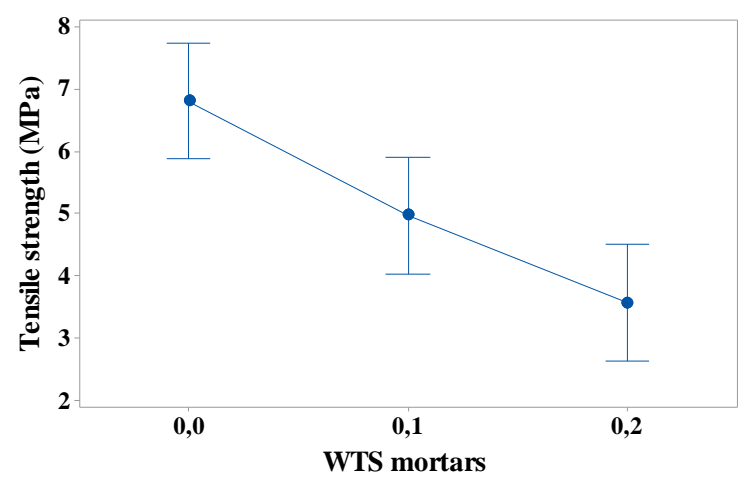

(b)

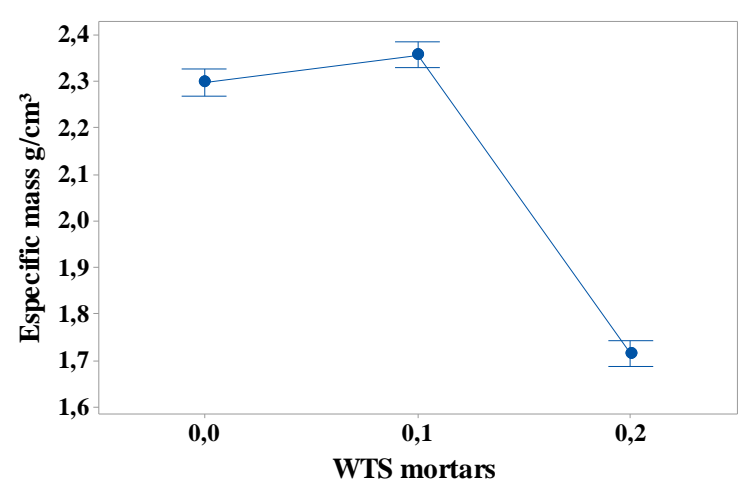

(d)

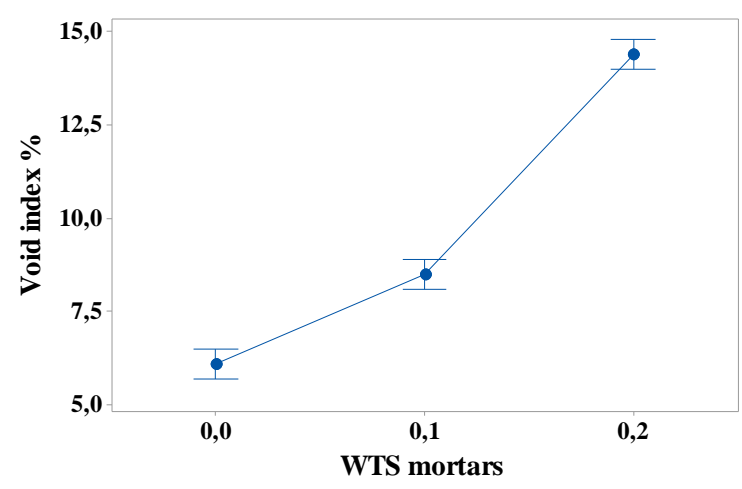

(f)

Source: Own Authors (2022).

Regarding the compression test, illustrated in Figure 8(a), there was a worsening of 65 and $70 \%$ in the results for the mixtures with 10 and 20\% of WTS, respectively. Oliveira Andrade et al. (2018) also verified lower compressive strengths, with the largest reductions occurring in the highest substitutions. In addition, the author found that strength increased over time, with the mixtures with calcined WTS having a slightly higher increase compared to the reference.

The decrease in compressive strength may be related to the higher w/c ratio of the mixtures with WTS (de Oliveira Andrade et al., 2018). Tafarel et al. (2016) also found an increase in the compressive strength of mixtures with wet sludge for longer curing times, although the values did not reach the strengths of the base mixture.

However, Brachini et al. (2020) reported an increase in compressive strength compared to the base mixture. This fact may be related to the lower w/c ratio used by the author and the larger amount of superplasticizer introduced in the mix. The 
calcination of WTS may influence, due to the reduction of organic matter, but it is in contrast to the results obtained by (de Oliveira Andrade et al., 2018).

For the tensile strength, Figure 8(b), the strengths presented reductions of 27 and $48 \%$ in the mortars with 10 and $20 \%$ of WTS, respectively. Furthermore, analyzing Figure 8(b), it can be seen that the tensile strength was one of the parameters that presented the highest standard deviation. Brachini et al (2020), also reported decreases in flexural tests with the introduction of sludge, referring to $21 \%$ for the mix with $20 \%$ of WTS. de Oliveira Andrade et al. (2018) and Ramirez et al. (2017) found decreases in tensile strength for their mortars and concretes using calcined and wet sludge. Tafarel et al. (2016) showed tensile strength for a 5\% substitution, using wet sludge, higher than the reference mix. According to Mehta \& Monteiro, (2008) this may be related to molding errors, curing time, and coarse aggregate characteristics, since the study dealt with concrete.

Regarding the modulus of elasticity, Figure 8(c), the mixtures with 10 and 20\% WTS showed reductions of 16 and $65 \%$, respectively. This result is directly related to the compressive strength, since both parameters are related. Ramirez et al. (2017) also verified decreases of this parameter in their concretes, however, for a mix with $10 \%$ wet sludge and a w/c ratio of 0.55 the reduction was $86.61 \%$, considerably higher than the result presented in Figure 8(c).

Based on the last analyzed parameters in Figure 8(d) - (f), they are intrinsically related to each other, depending mainly on the w/c ratio and the amount of organic matter present in the sludge (Hoppen et al., 2005). The specific gravity for $10 \%$ and $20 \%$ WTS is slightly increased by $3 \%$ and greatly decreased by $34 \%$. At $10 \%$ WTS since it is a small portion of WTS, it did not significantly affect the specific gravity. But for $20 \%$ WTS there is a large variation. This may be due to the lower specific mass of the sludge, whose value, in this study, corresponds to $77 \%$ of the density of the cement it replaced.

According to Ramirez et al. (2017), the voids content is linked to the w/c ratio. This possibly causes mixtures containing WTS to have higher porosity and, consequently, higher water absorption. Such an issue can justify the increase in the void ratio from approximately $40 \%$ to $137 \%$ and in water absorption from $43 \%$ to $160 \%$ of mortars with $10 \%$ and $20 \%$ of WTS, respectively.

In addition, absorption is an extremely important analysis, since the most common way for aggressive agents to enter concrete is through its pore system, which may have water as a vector (Ramirez et al. 2017).

Moreover, for the parameters illustrated in Figure 9(a) - (f), it is observed that the results for each mixture are consistent, with low standard deviation, i.e., the values obtained for each specimen are close to the calculated mean. Besides the analysis of variance, Fisher's test was applied, obtaining the results shown in Figure 9. 
Figure 9: Fisher's test for mortars with WTS.

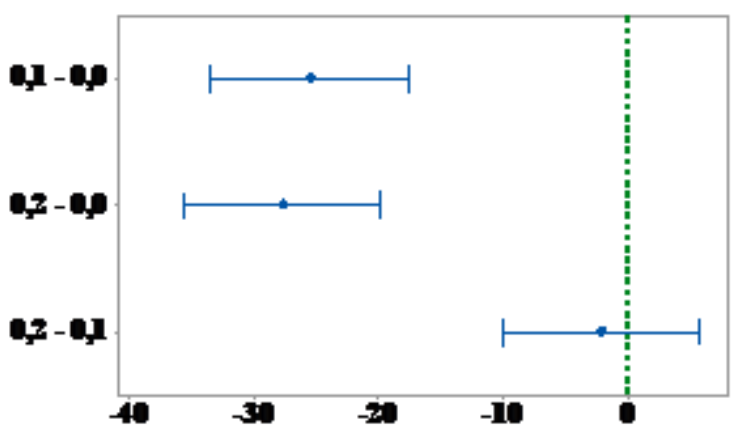

(a)

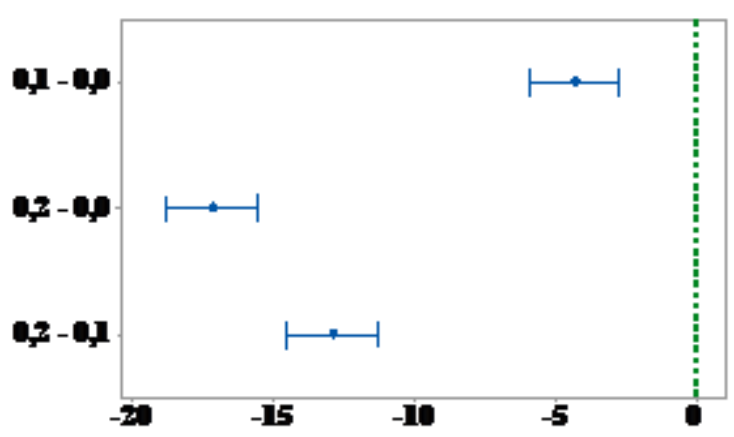

(c)

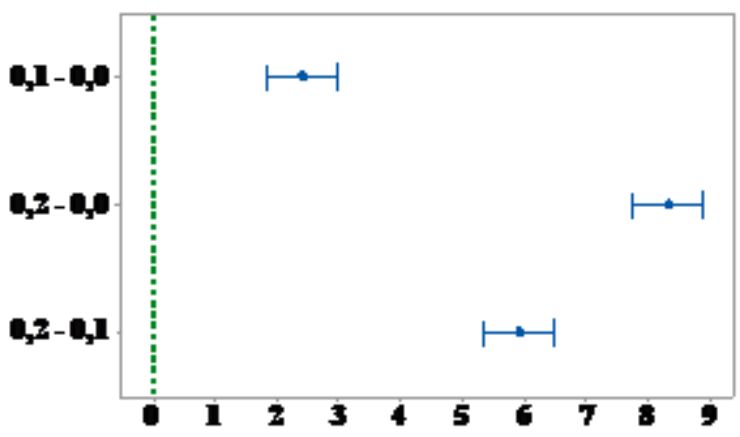

(e)

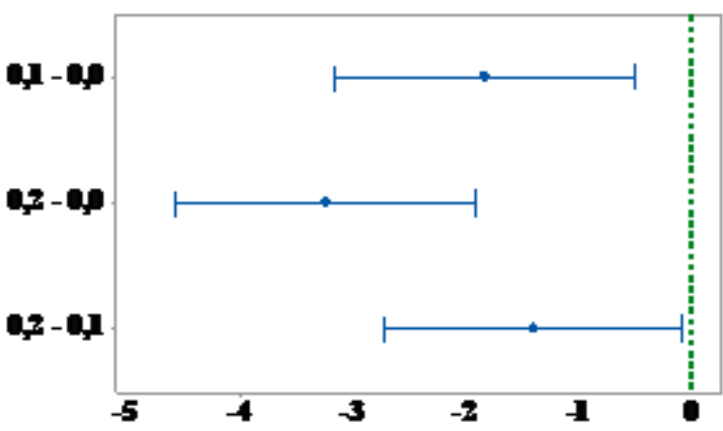

(b)

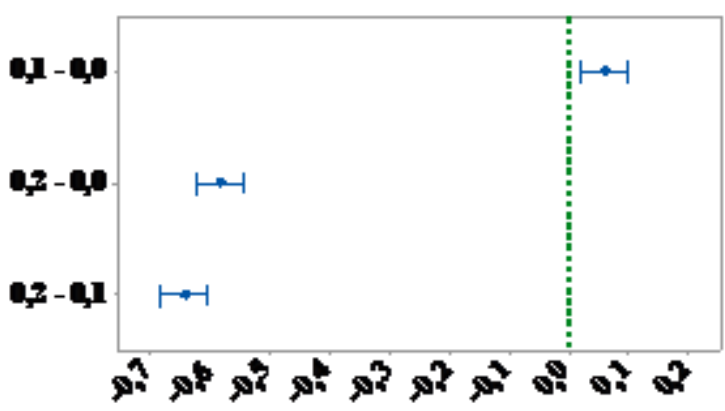

(d)

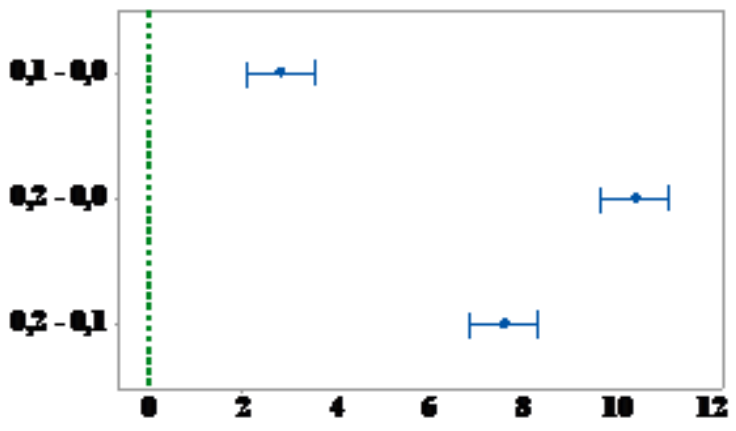

(f)

Source: Own Authors (2022).

Through the analysis performed and the graphs presented, it is possible to verify, statistically, the proximity between each mixture. It can be observed that the compression test, in Figure 9(a) - (f), does not show significant differences for the substitutions of 10 and $20 \%$. For the other parameters, the results obtained for each mixture have significant differences.

Moreover, for Ramirez et al. (2017), the mechanical parameters are reduced, mainly, for substitutions above $7 \%$. According to Hoppen et al.(2005), concretes with up to 5\% of WTS are feasible. 


\section{Conclusion}

This study proposed to evaluate the addition of water treatment plant sludge in self-compacting Portland cement mortar. The following conclusions can be drawn:

In the fresh state, the incorporation of WTS caused slight modifications in the spreading properties. For the $10 \%$ and $20 \%$ of WTS there was an increase of $0.3 \%$ and decrease of $1.0 \%$. And also, slight modifications in the flow properties, and for the $10 \%$ and $20 \%$ of WTS occurred a decrease of $0.2 \%$ and $0.3 \%$.

In the hardened state regarding the compressive strength for $10 \%$ and $20 \%$ of WTS a decrease of 65 and $70 \%$ was observed. The tensile strength decreased by 27 and $48 \%$ and modulus of elasticity decreased by $10 \%$ and $20 \%$.

The specific mass was only significantly altered with replacement of $20 \%$ WTS, with a decrease of $34 \%$. The void index was greatly altered, with increases occurring from $40 \%$ to $137 \%$. The same occurred with water absorption with increases from $43 \%$ to $160 \%$.

Through the results and literature analysis, the authors recommend caution in the use of WTS in cementitious materials. Since there is a great loss of mechanical properties and a worsening in the physical properties analyzed. Thus, the use of WTS in mortar can be done in non-structural applications and in non-aggressive environments, given the high-water absorption and voids index presented by mortars with WTS.

As future studies are recommended to verify the behavior of Portland cement-based mortars with WTS contents below $10 \%$, in order to obtain a material with WTS but with minimal loss of properties in the hardened state. Another important field of study is the analysis of the durability of mortars with WTS. For job suggestions futures suggests to investigate the microstructure and relate them to the physical and mechanical properties.

\section{References}

ABNT. (2004). NBR 10004: Resíduos sólidos - Classificação (Solid waste - Classification). In Associação Brasileira de Normas Técnicas: Vol. $2^{\circ}$ Edição (Issue 10004, pp. 1-71).

ABNT NBR 15900. (2009). NBR 15900-1: Água para amassamento do concreto Parte 1: Requisitos. Abnt, 237.

Ahmad, T., Ahmad, K., \& Alam, M. (2016). Sustainable management of water treatment sludge through 3'R' concept. Journal of Cleaner Production, 124, 113. https://doi.org/10.1016/j.jclepro.2016.02.073

Araújo, F. C., Scalize, P. S., Albuquerque, A., \& Angelim, R. R. (2015). Caracterização física do resíduo de uma estação de tratamento de água para sua utilização em materiais de construção. Ceramica, 61(360), 450-456. https://doi.org/10.1590/0366-69132015613601931

Babatunde, A., \& Zhao, Y. (2007). Constructive Approaches Toward Water Treatment Works Sludge Management: An International Review of Beneficial Reuses. Critical Reviews in Environmental Science and Technology, 37, 129-164. https://doi.org/10.1080/10643380600776239

Brachini, M. L. O., Santos, V. C., Gonçalves, P. C., Mirian, L. N. M., \& Oliveira, V. D. (2020). Utilização do lodo de tratamento de água em argamassas auto adensáveis Use of water treatment sludge in self-compacting mortars Resumo. 1, 1-14.

Buselatto, D. M., Wenzel, M. C., Da Rocha, G. H., Webber, J., Da Silva, S. R., \& De Oliveira Andrade, J. J. (2019). Use of water treatment sludge (WTS) as fine aggregate in concretes: Evaluation of physical-mechanical properties. Revista Materia, 24(1). https://doi.org/10.1590/s1517-707620190001.0645

Câmara dos Deputados. (2017). Política Nacional de Resíduos Sólidos. (3a ed.), Câmara dos Deputados, Edições Câmara.

Comminal, R., Leal da Silva, W. R., Andersen, T. J., Stang, H., \& Spangenberg, J. (2020). Modelling of 3D concrete printing based on computational fluid dynamics. Cement and Concrete Research, 138, 106256. https://doi.org/https://doi.org/10.1016/j.cemconres.2020.106256

de Oliveira Andrade, J. J., Wenzel, M. C., da Rocha, G. H., \& da Silva, S. R. (2018). Performance of rendering mortars containing sludge from water treatment plants as fine recycled aggregate. Journal of Cleaner Production, 192, 159-168. https://doi.org/10.1016/j.jclepro.2018.04.246

Dinakar, P. (2012). Design of self-compacting concrete with fly ash. Magazine of Concrete Research, 64(5), 401-409. https://doi.org/10.1680/macr.10.00167 Eaton, A. D; Clesceri, L. S; Rice, E. W.; Greenberg, A. E. (2007). Standart methods for the examination of water and wastewater (23rd ed.).

Gomes, P. C. C.; Barros, A. R. (2009). Métodos de Dosagem de Concreto Autoadensável. (Pini (ed.); $1^{\circ}$ ).

Hoppen, C., Portella, K. F., Joukoski, A., Baron, O., Franck, R., Sales, A., Andreoli, C. V, Paulon, V. A., Carlos, S., \& Campinas, U. E. De. (2005). Codisposição de lodo centrifugado de Estação de Tratamento de Água ( ETA ) em matriz de concreto : método alternativo de preservação ambiental ( Disposal of centrifuged sludge from Water Treatment Plant ( WTP) in concrete matrix: an alternative method. Cerâmica, 51, 85-95. 
https://www.scielo.br/scielo.php?script=sci_issuetoc\&pid=0366-691320050002\&lng=pt

Katayama, V. T., Montes, C. P., Ferraz, T. H., \& Morita, D. M. (2015). Quantificação da produção de lodo de estações de tratamento de água de ciclo completo: Uma análise crítica. Engenharia Sanitaria e Ambiental, 20(4), 559-569. https://doi.org/10.1590/S1413-41522015020040105046

Liu, Y., Zhuge, Y., Chow, C. W. K., Keegan, A., Li, D., Pham, P. N., Huang, J., \& Siddique, R. (2020). Utilization of drinking water treatment sludge in concrete paving blocks: Microstructural analysis, durability and leaching properties. Journal of Environmental Management, 262, 110352. https://doi.org/https://doi.org/10.1016/j.jenvman.2020.110352

Medina, E. A. (2011). Pozolanicidade do metacaulim em sistemas binários com Cimento Portland e hidróxido de cálcio. (Dissertação de Mestrado). Universidade de São Paulo., 134.

Mehta, P. K.; \& Monteiro, P. J. M. (2008). Concreto: microestrutura, propriedades e materiais (Ibracon (ed.)).

Ministério do Desenvolvimento Regional. (2020). Sistema Nacional de Informações sobre Saneamento: Diagnóstico dos serviços de água e esgoto - 2019. Sistema Nacional de Informações Sobre Saneamento - SNIS, 44(8), 1689-1699.

Okamura, H., \& Ouchi, M. (2003). Self-Compacting Concrete. Journal of Advanced Concrete Technology, 1(1), 5-15. https://doi.org/10.3151/jact.1.5

Ramirez, K. G., Possan, E., Dezen, B. G. dos S., \& Colombo, M. (2017). Potential uses of waste sludge in concrete production. Management of Environmental Quality: An International Journal, 28(6), 821-838. https://doi.org/10.1108/MEQ-09-2015-0178

Ribeiro, R. F. (2012). Estudo De Dosagem De Lodo De Estação De Tratamento De Água ( Eta ) Em Argamassa. Trabalho de Conclusão de Curso Em Engenharia Ambiental. Universidade Tecnológica Federal Do Paraná., 1-61.

Ribeiro, V. A. dos S. R., Werdine, D., Barbosa, L. F., Oliveira, A. F., Barbosa, A. M., Silva, L. R. R., \& Ribeiro, L. H. (2021). Investigação das propriedades físicas e mecânicas do concreto convencional com substituição parcial da areia pelas fibras de bambu Investigation of the physical and mechanical properties of conventional concrete with partial replacement of sand by bamboo. 2021(2014), 1-11.

Ribeiro, V. A. dos S., Werdine, D., Barbosa, L. F., Oliveira, A. F., \& Santana, L. P. (2021). Investigação das propriedades do concreto convencional com adição de resíduos de pneu e metacaulim. Research, Society and Development, 10(5), e2410514463. https://doi.org/10.33448/rsd-v10i5.14463

Rodrigues, F., Valle, S., Cesar, P., Gabriela, M., \& Ranieri, A. (2022). Use of recycled aggregates from civil construction in self- compacting mortar. 15(1), 113.

Sales, A.; \& Souza, F. R. de. (2005). Concretos e Argamassas Reciclados com Adição Conjunta e Exclusiva de LETAs e RCDs. CBECIMAT.

Santos, Géssica Zila Batista dos. (2016). Argamassa geopolimérica à base de lodo de estação de tratamento de água calcinado. Dissertação de Mestrado Em Engenharia Civil. Universidade Federal Do Amazonas, 115.

Santos, Gessica Zila Batista dos, Melo Filho, J. de A., \& Manzato, L. (2018). Perspectivas de aplicações tecnológicas de lodo gerado no processo de tratamento de água dos rios Negro e Solimões. Matéria (Rio de Janeiro), 23(3). https://doi.org/10.1590/s1517-707620180003.0501

Silva, L. R. R. da, Silva, J. A. da, Francisco, M. B., Ribeiro, V. A., de Souza, M. H. B., Capellato, P., Souza, M. A., dos Santos, V., Cesar Gonçalves, P., \& de Lourdes Noronha Motta Melo, M. (2020). Polymeric Waste from Recycling Refrigerators as an Aggregate for Self-Compacting Concrete. Sustainability, 12(20). https://doi.org/10.3390/su12208731

Sogancioglu, M., Yel, E., \& Yilmaz, U. (2013). Utilization of andesite processing wastewater treatment sludge as admixture in concrete mix. Construction and Building Materials, 46, 150-155. https://doi.org/10.1016/j.conbuildmat.2013.04.035

Souza, M. H. B. de, Gonçalves, P. C., Silva, L. R. R., Melo, M. de L. N. M., \& Santos, V. C. dos. (2021). Use of superabsorbent polymers in cement-based compounds: a bibliometric analysis. Research, Society and Development, 10(14), e171101421818. https://doi.org/10.33448/rsd-v10i14.21818

Tafarel, N. F., Macioski, G., De Carvalho, K. Q., Nagalli, A., De Freitas, D. C., \& Passig, F. H. (2016). Avaliação das propriedades do concreto devido à incorporação de lodo de estação de tratamento de água. Revista Materia, 21(4), 974-986. https://doi.org/10.1590/S1517-707620160004.0090

Yagüe, A., Valls, S., Vázquez, E., \& Albareda, F. (2005). Durability of concrete with addition of dry sludge from waste water treatment plants. Cement and Concrete Research, 35, 1064-1073. https://doi.org/10.1016/j.cemconres.2004.07.043 